OPEN

SUBJECT AREAS:

RHO SIGNALLING

CELL PROLIFERATION

Received

11 November 2014

Accepted

4 March 2015

Published

24 March 2015

Correspondence and requests for materials should be addressed to B.Y. (2424572228@

qq.com)

* These authors contributed equally to this work.

\section{Annexin V-induced rat Leydig cell proliferation involves Ect2 via RhoA/ROCK signaling pathway}

Jun Jing*, Li Chen*, Hai-Yan Fu, Kai Fan, Qi Yao, Yi-Feng Ge, Jin-Chun Lu \& Bing Yao

Center of Reproductive Medicine, Nanjing Jinling Hospital, Nanjing University School of Medicine, Nanjing 210002, China.

This study investigated the effect of annexin $\mathrm{V}$ on the proliferation of primary rat Leydig cells and the potential mechanism. Our results showed that annexin V promoted rat Leydig cell proliferation and cell cycle progression in a dose- and time-dependent manner. Increased level of annexin $\mathrm{V}$ also enhanced Ect2 protein expression. However, siRNA knockdown of Ect2 attenuated annexin V-induced proliferation of rat Leydig cells. Taken together, these data suggest that increased level of annexin $\mathrm{V}$ induced rat Leydig cell proliferation and cell cycle progression via Ect2. Since RhoA activity was increased following Ect2 activation, we further investigated whether Ect2 was involved in annexin $\mathrm{V}$-induced proliferation via the RhoA/ROCK pathway, and the results showed that annexin V increased RhoA activity too, and this effect was abolished by the knockdown of Ect2. Moreover, inhibition of the RhoA/ROCK pathway by a ROCK inhibitor, Y27632, also attenuated annexin V-induced proliferation and cell cycle progression. We thus conclude that Ect2 is involved in annexin V-induced rat Leydig cell proliferation through the RhoA/ROCK pathway.

nnexin $\mathrm{V}$ is a member of the annexin family of proteins, which consist of 12 annexins in mammals ${ }^{1}$. Common features among the annexins include structural similarities and calcium-dependent phospholipid binding. Annexin V was first identified as a protein with structural similarity to annexin I, a mediator of the anti-inflammatory activity of glucocorticoids via inhibition of phospholipase $\mathrm{A} 2^{2,3}$ and an inhibitor of blood coagulation ${ }^{4}$. Annexin $\mathrm{V}$ also shows protein kinase $\mathrm{C}$-inhibitory activity ${ }^{5}$, and it forms calcium channels on phospholipid membranes ${ }^{6}$. Although the biochemical properties suggest important roles of annexin family proteins in cell functions, the function of these proteins in physiological process is still obscure ${ }^{7}$. It is synthesized in the anterior pituitary gland ${ }^{8}$ and produced by pituitary gonadotropes under the regulation of gonadotropin releasing hormone $(\mathrm{GnRH})^{9-12}$. Kawaminami et al. found that annexin $\mathrm{V}$ was expressed in the regressing corpus luteum ${ }^{13}$. The expression of annexin $\mathrm{V}$ in luteal cells was accompanied by apoptotic change that was inhibited by local administration of a GnRH receptor antagonist, thus annexin $\mathrm{V}$ synthesis is stimulated by GnRH in the ovary.

Leydig cells are the main source of steroid hormones in the mammalian testis, preserving the normal functions of which determines the reproductive capacity and fertility of males. Testosterone is primarily produced by adult Leydig cells and is important to maintain spermatogenesis and secondary sexual characteristics. It has been reported that annexin $\mathrm{V}$ is expressed by Leydig and Sertoli cells in rat ${ }^{14,15}$. Annexin $\mathrm{V}$ and 3- $\beta$-hydroxysteroid dehydrogenase (HSD) were also shown to colocalize in the Leydig cells ${ }^{16}$. Our previous studies showed that GnRH agonist increased the mRNA and protein levels of annexin $\mathrm{V}$ in primary rat Leydig cells in vitro ${ }^{17}$, as well as the secretion of testosterone ${ }^{18}$, annexin $\mathrm{V}$ could increase testosterone production and promote cell proliferation of Leydig cells. During the puberty, the proliferation of Leydig cell precursors is required to increase the number of Leydig cells. In this study, we found the existence of functional relationship between annexin $\mathrm{V}$ and Leydig cell proliferation. With the method of differential proteomics, a total of 33 proteins were identified as differentially expressed in annexin V-treated Leydig cells ${ }^{19}$. Among these proteins, Ect2 was correlated with Leydig cell proliferation and chosen for further study. The upregulation of Ect2 implied a subtle cell proliferation trend induced by annexin $\mathrm{V}$.

Based on these data, we hypothesize that upregulation of Ect2 contributes to rat Leydig cell proliferation induced by exogenous annexin $\mathrm{V}$. Thus the present study aimed to examine the effects of annexin $\mathrm{V}$ on Ect2 expression and its potential link with the proliferation of rat Leydig cells. The potential mechanisms of Leydig cell proliferation may offer new opportunities for treating testosterone deficiency. 

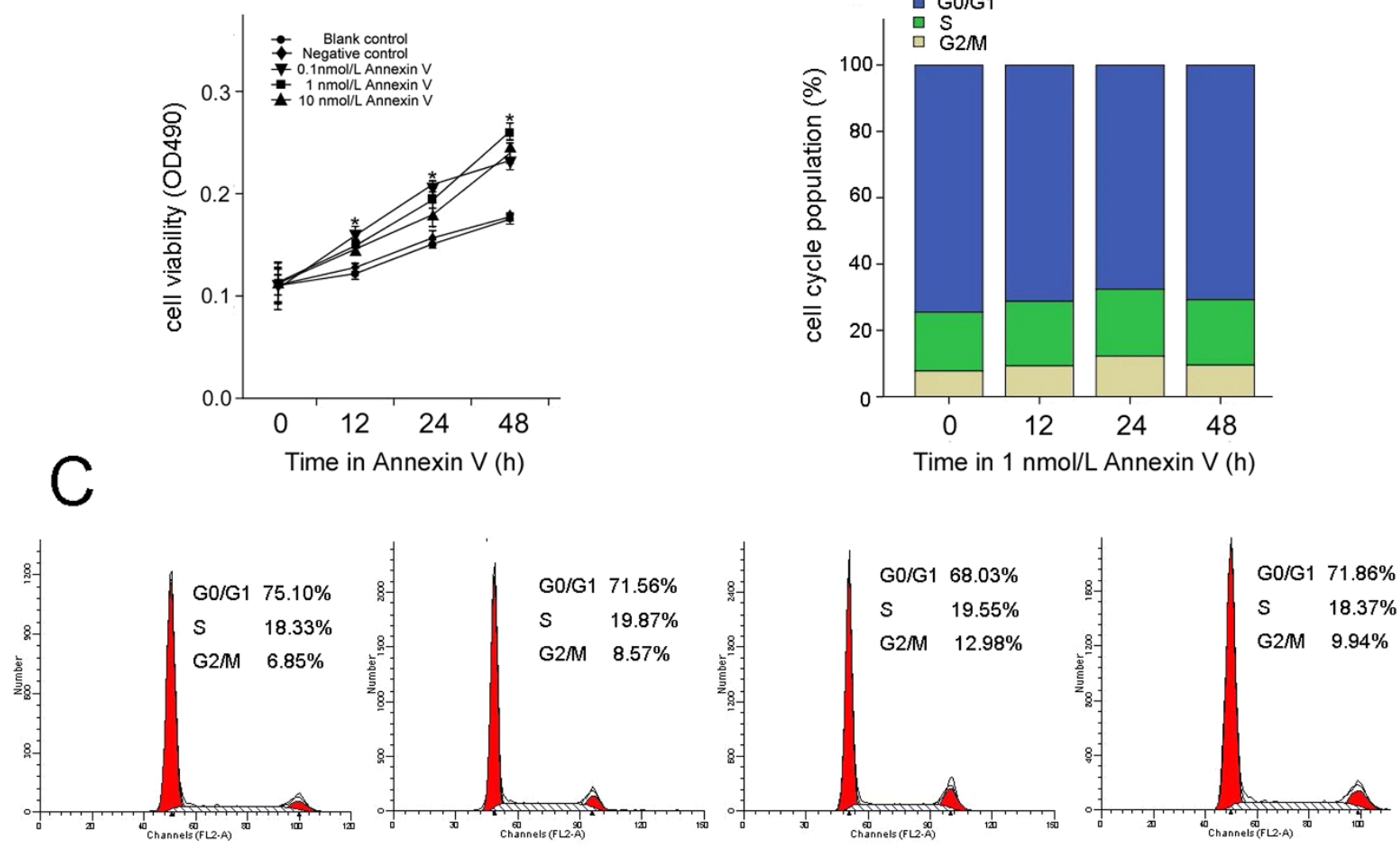

Figure 1 The influence of annexin V on rat Leydig cell proliferation and cell cycle progression. (A) Cell proliferation was increased after treated with different concentrations of annexin V in comparison with blank control and negative control, as determined by the MTT assay; the results are

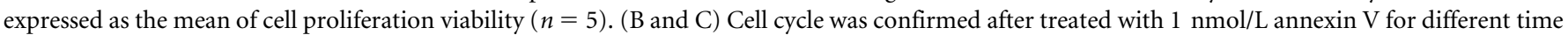

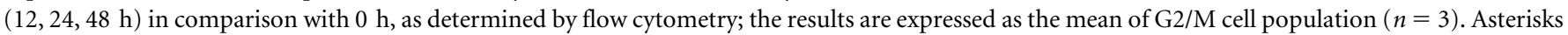
indicate the statistical significance $(* P<0.01)$, vs. Blank control.

\section{Results}

Annexin V promotes rat Leydig cell proliferation and cell cycle progression. Proliferation viability of rat Leydig cells exposed to different concentrations of annexin $\mathrm{V}$ for $0-48 \mathrm{~h}$ was assessed by MTT assay (Fig. 1A). No differences were observed in Leydig cell viability between the negative control and the blank control groups $(P>0.05 ; n=5)$ in different time periods. However, the cell viability increased compared to the blank control group when Leydig cells were treated with $0.1-10 \mathrm{nmol} / \mathrm{L}$ annexin V for $12-48 \mathrm{~h}(P<0.01 ; n$ $=5)$. Significant increase in proliferation viability occurred under $1 \mathrm{nmol} / \mathrm{L}$ annexin $\mathrm{V}$ at $48 \mathrm{~h}$. Compared with the blank control, the cell proliferation viability was increased by $49 \%$ under $1 \mathrm{nmol} / \mathrm{L}$ annexin $\mathrm{V}$ treatment $(P<0.01 ; n=5)$.

The effect of annexin $\mathrm{V}$ on the cell cycle of rat leydig cells was evaluated using flow cytometry, and the obtained results are illustrated in Fig. 1B and C. After 24 and $48 \mathrm{~h}$ exposure to $1 \mathrm{nmol} / \mathrm{L}$ annexin $\mathrm{V}$, the $\mathrm{G} 0 / \mathrm{G} 1$ cell population decreased $(P<0.01 ; n=3)$ compared with the control group, while the G2/M cell population significantly increased ( $P<0.01 ; n=3)$. Although the differences were not significant, compared with the control group $(P<0.05 ; n=$ 3 ) the $\mathrm{G} 2 / \mathrm{M}$ cell population increased after $1 \mathrm{nmol} / \mathrm{L}$ annexin $\mathrm{V}$ treatment for $12 \mathrm{~h}$. For the $S$ phase population, there was an insignificant but numerical increase $(P>0.05 ; n=3)$ under $1 \mathrm{nmol} / \mathrm{L}$ annexin $\mathrm{V}$ treatment from 12 to $48 \mathrm{~h}$.

Annexin $\mathrm{V}$ increases the protein expression levels of Ect2. To investigate the mechanism of annexin $\mathrm{V}$ affecting Leydig cell proliferation, we used Western blot to detect the change of Ect 2 protein level. The effects of annexin $\mathrm{V}$ on Ect2 expression were in a dosedependent manner (Fig. 2A). Significant increase in Ect2 protein expression occurred under $1 \mathrm{nmol} / \mathrm{L}$ annexin $\mathrm{V}$. Compared with the blank control, the protein expression of Ect 2 was increased by $18 \%$ under $1 \mathrm{nmol} / \mathrm{L}$ annexin $\mathrm{V}$ treatment $(P<0.05 ; n=3)$. However, no differences were observed in the protein expression of Ect 2 between the negative control and blank control $(P>0.05$; $n=3)$. Annexin $\mathrm{V}(1 \mathrm{nmol} / \mathrm{L})$ also displayed a time-dependent effect on Ect2 expression, as shown in Fig. 2B. The protein expression of Ect 2 was increased by $61 \%$ and $113 \%$ under $1 \mathrm{nmol} / \mathrm{L}$ annexin $\mathrm{V}$ at 24 and 48 h respectively $(P<0.01 ; n=3)$. However, there was a trend of insignificant increase $(P>0.05 ; n=3)$ under $1 \mathrm{nmol} / \mathrm{L}$ annexin $\mathrm{V}$ treatment at $12 \mathrm{~h}$.

Blockage of Ect 2 activity attenuates rat Leydig cell proliferation. To examine the silencing effect of siRNAs-Ect2 on Ect2 protein expression, we transfected the 3 siRNA duplexes and the scrambled siRNA into Leydig cells respectively. After transfection for $48 \mathrm{~h}$, the cells were collected for Western blotting. Compared with the blank control, 2 duplexes showed an inhibitory effect on Ect2 expression, and the protein expression of Ect 2 decreased by $24 \%$ and $49 \%$ respectively $(P<0.01 ; n=3)$; siRNA-3 was the best among the 3 duplexes (Fig. 3).

To further explore the role of Ect2 in annexin V-induced Leydig cell proliferation, we employed siRNA to assess the effect of Ect2 depletion on annexin V-induced proliferation using MTT assay and flow cytometric analysis. The administration of $1 \mathrm{nmol} / \mathrm{L}$ annexin $\mathrm{V}$ for $48 \mathrm{~h}$ caused a significant increase in cell proliferation 

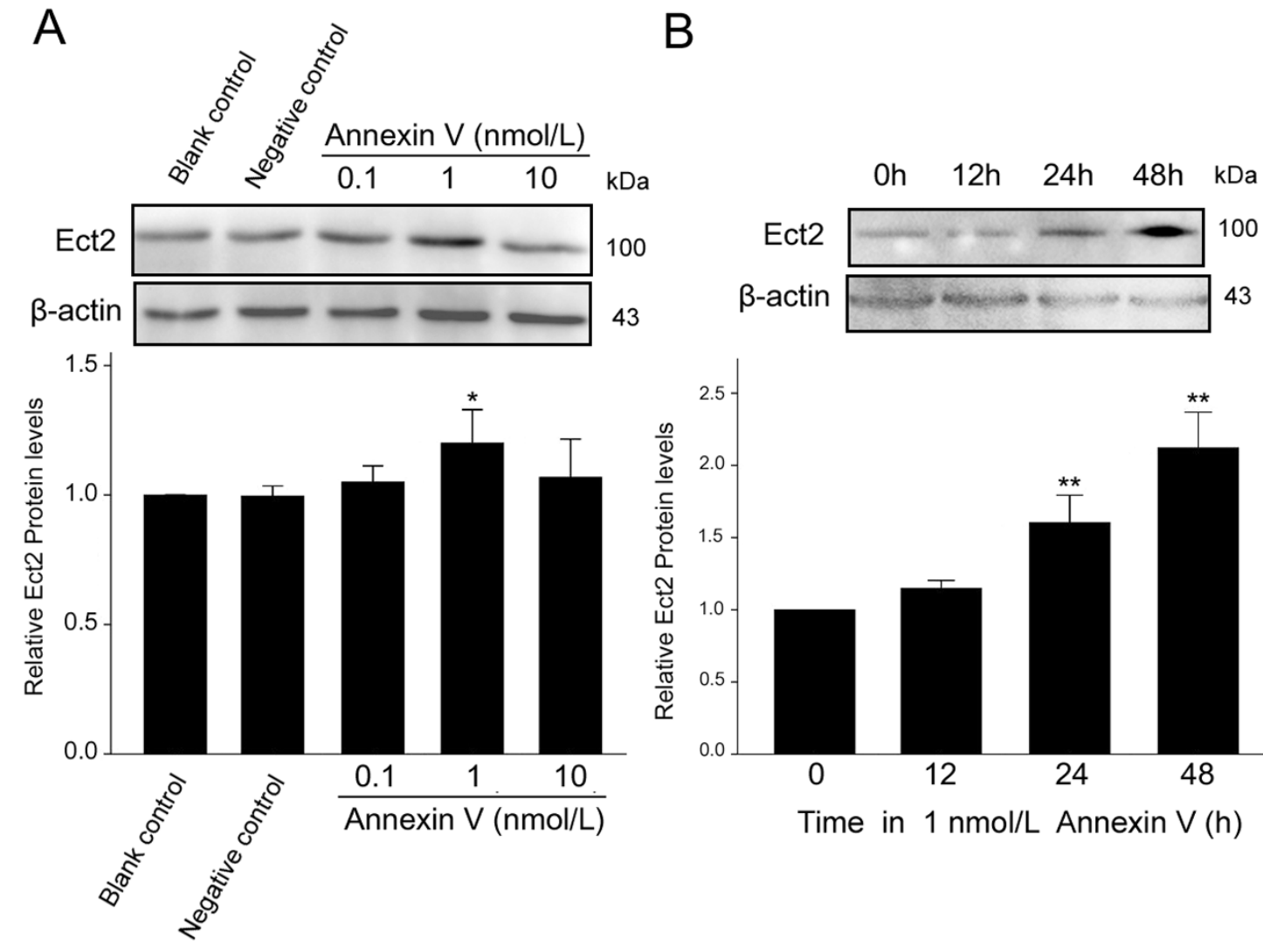

Figure $2 \mid$ The influence of annexin $\mathrm{V}$ on Ect2 protein expression in rat Leydig cells. The cells were treated with annexin $\mathrm{V}$ in comparison with blank control and negative control, and the protein expression of Ect2 was detected by Western blotting. Annexin $\mathrm{V}$ increased Ect2 protein levels in a dose(A) and time-dependent $(\mathrm{B})$ manner $(n=3)$. Asterisks indicate the statistical significance $\left(* P<0.05,{ }^{* *} P<0.01\right)$, vs. Blank control.

viability in contrast with control $(P<0.01 ; n=5$; Fig. 4A). Flow cytometry analysis further indicated that the G2/M cell population was significantly increased in annexin $\mathrm{V}$ group in contrast with the control group (Fig. 4B and C). However, the increase in both the cell proliferation viability and the G2/M cell population induced by annexin $\mathrm{V}$ was significantly inhibited by transfection with Ect2siRNA (Fig. 4), compared with non-transfected cells and cells transfected with scrambled siRNA, suggesting the involvement of Ect2 in annexin V-induced proliferation.

Ect2 participates in annexin $\mathrm{V}$-induced Leydig cell proliferation via RhoA/ROCK signaling pathway. RhoA activity was measured by an affinity pull-down assay using the GST fusion protein rhotekin that only recognizes the active form of RhoA (GTPRhoA). Treatment with $1 \mathrm{nmol} / \mathrm{L}$ annexin $\mathrm{V}$ for $48 \mathrm{~h}$ caused a significant increase in RhoA activity in contrast with control $(P<$ $0.01 ; n=3$; Fig. 5). This effect may contribute to annexin $\mathrm{V}$-induced Leydig cell proliferation, because transfection with Ect2-siRNA attenuated annexin $\mathrm{V}$-induced increase in RhoA activity (Fig. 5), compared with non-transfected cells or cells transfected with the scrambled siRNA $(P<0.01 ; n=3)$. If the RhoA/ROCK pathway activation promotes Ect2-dependent G2/M cell population increase in annexin $\mathrm{V}$-induced Leydig cell proliferation, inhibition of this down-stream pathway should attenuate the effect of annexin V. We thus measured the effect of Y27632, a selective ROCK inhibitor, on the annexin $\mathrm{V}$-induced proliferation and found that the increase in both the cell proliferation viability and the G2/M cell population induced by annexin $\mathrm{V}$ was significantly inhibited by the concurrent administration of $\mathrm{Y} 27632(10 \mu \mathrm{mol} / \mathrm{L}$; Fig. 6), indicating the involvement of RhoA/ROCK pathway in Ect2-dependent G2/M cell population increase during annexin $\mathrm{V}$-induced Leydig cells proliferation.
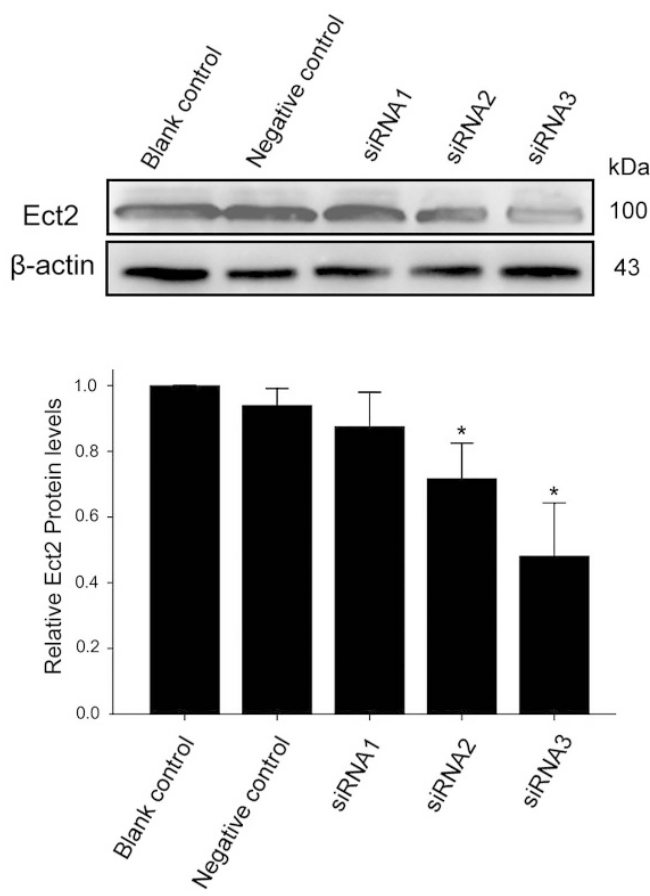

Figure 3 The inhibitory effect of siRNA duplexes on Ect2 expression in rat Leydig cells. The cells were transfected with 3 different siRNAs $(100 \mathrm{nmol} / \mathrm{L})$ in comparison with blank control and negative control (scrambled siRNA) for $48 \mathrm{~h}$, and the protein expression of Ect2 was detected by Western blotting $(n=3)$. The protein expression of Ect2 decreased significantly by $24 \%$ and $49 \%$, respectively, for siRNA 2 and siRNA3. ${ }^{*} P<0.05$, compared with Negative control. 
A
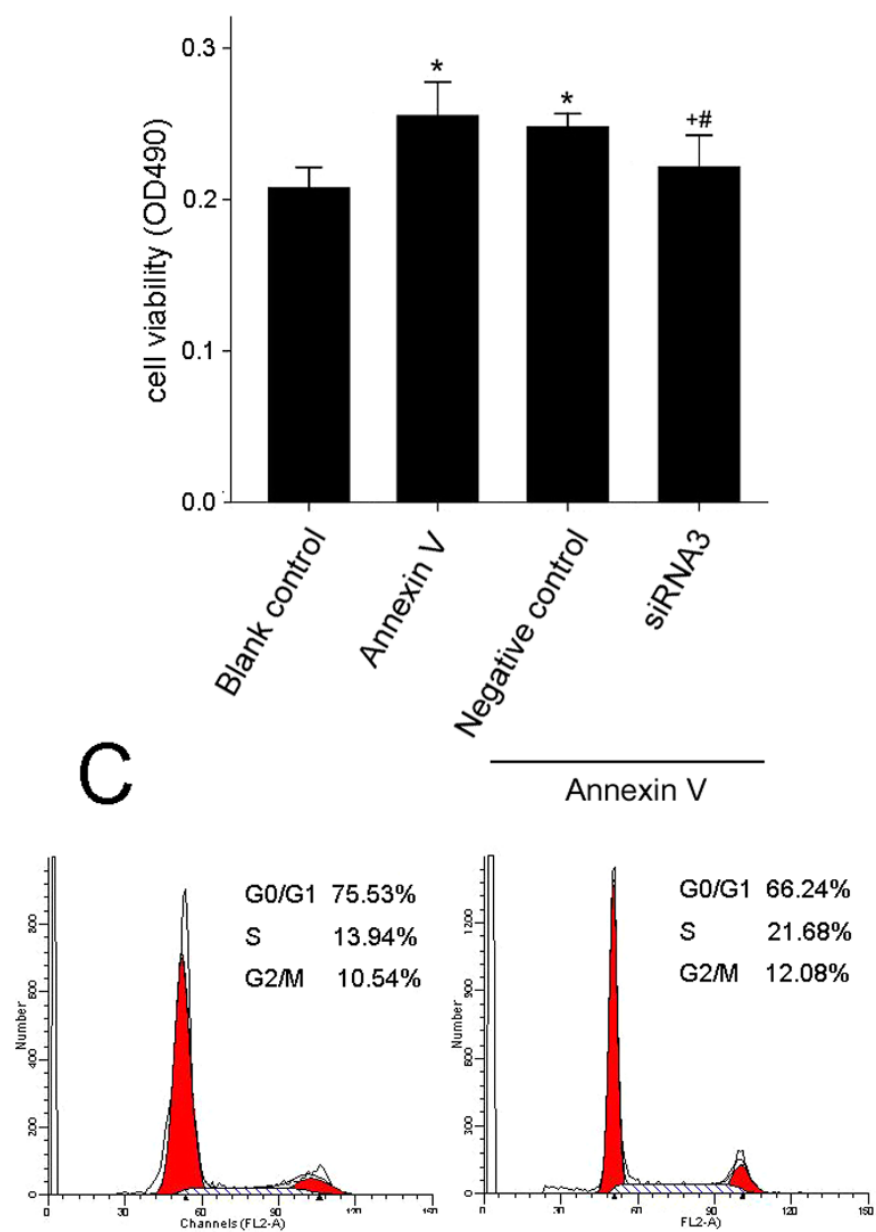
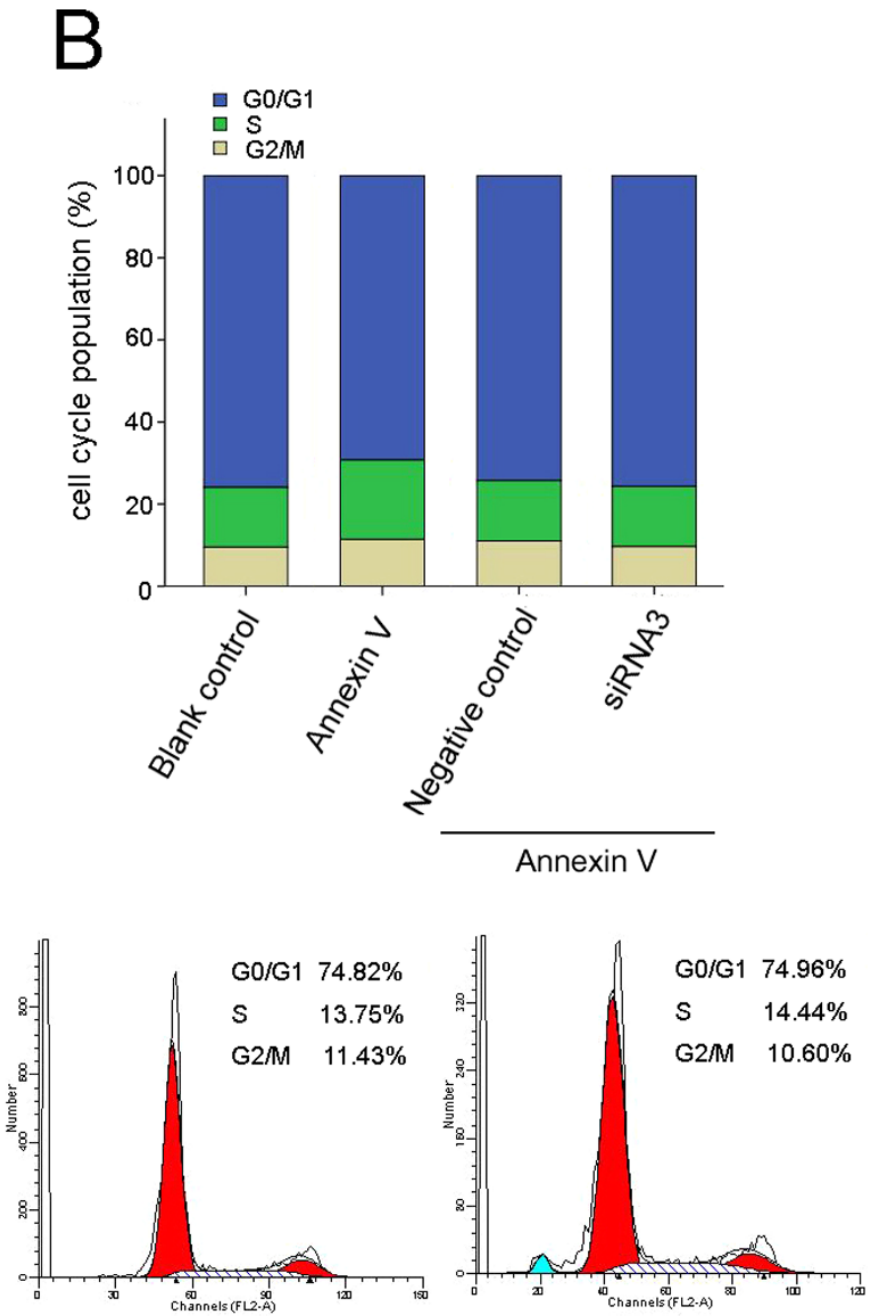

Figure $4 \mid$ Annexin V-induced Leydig cell proliferation was attenuated by depletion of Ect2. The cells were transfected without or with siRNA3 or scrambled siRNA (negative control) followed by treatment with blank control or annexin $\mathrm{V}$ for $48 \mathrm{~h}$. (A) The cell proliferation was determined using MTT assay; the results are expressed as cell proliferation viability $(n=5)$. (B and C) Cell cycle was confirmed using flow cytometry; the results are expressed as the G2/M cell population $(n=3) .{ }^{*} P<0.01$ vs Blank control; $+P<0.01$ vs. annexin $\mathrm{V}$; and $\# P<0.05$ vs. annexin $\mathrm{V}+\mathrm{Negative}$ control.

\section{Discussion}

This study revealed that annexin $\mathrm{V}$ promoted rat Leydig cell proliferation in a dose- and time-dependent manner. Meanwhile, flow cytometry showed a significant increase of cells in the G2/M phase. Cell proliferation viability was related to the sum of cells in S and G2/ $\mathrm{M}$ phase of cell cycle, so increasing the transition from the G2 phase to $\mathrm{M}$ phase promoted cell proliferation viability of rat Leydig cells. We also demonstrated that Ect2 was involved in annexin V-induced proliferation of rat Leydig cells. Ect2, the epithelial cell transforming sequence 2 oncogene, was found in 1993 by Miki et al. in epithelial cells, which is located on chromosome $3 \mathrm{q} 26^{20}$. The C-terminal of the Ect2 protein catalyzes guanine nucleotide exchange on the Rho family of small GTPases, while the N-terminal contains a domain related to cell cycle regulator/checkpoint control protein ${ }^{21}$. The expression of this gene is elevated with the onset of DNA synthesis and remains elevated during G2 and $M$ phases ${ }^{22}$. In situ hybridization analysis showed that Ect2 was highly expressed in mitotic cells during liver regeneration ${ }^{23}$. These results suggest that Ect2 is an important player in cell cycle machinery involved in the regulation of cell division.

We also found that Ect2 knockdown by siRNA attenuated the annexin $\mathrm{V}$-induced rat Leydig cell proliferation. A previous study reported that microinjection of affinity-purified anti-Ect 2 antibody into interphase cells also inhibited cytokinesis ${ }^{24}$, while depletion of
Ect2 by siRNA oligonucleotides reduced the rate of glioblastoma cell proliferation too ${ }^{25}$.

Taken together, these findings suggest that there is a common mechanism by which Ect2-dependent G2/M cell population increase contributes to the annexin $\mathrm{V}$-induced cell proliferation. Ect2, a guanine nucleotide exchange factor (GEF) that activates RhoA during cytokinesis, is regulated by phosphorylation and subcellular localization $^{26}$. Expression of the dominant negative form of Ect 2 completely suppressed both the rise of GTP-Rho in the telophase and the increased GDP-GTP exchange activity in the mitotic cell extracts ${ }^{27}$. Ect2 is normally in an inactive conformation, partially due to the intramolecular interaction between the BRCT domains and the Cterminal domain of Ect2, which blocks its catalytic activity for guanine nucleotide exchange toward Rho ${ }^{28}$. This impact on Rho signaling was accompanied by reduced junctional localization of Ect 2 and the centralspindlin complex containing Ect $2^{29}$. A previous study found that Ect 2 first becomes active in prophase during its translocation from the nucleus into the cytoplasm, activating RhoA to induce the formation of metaphase cortex ${ }^{30}$. The $\mathrm{PH}$ domain is required for the cortical localization of Ect2, but its molecular function is not known. In cultured human cells, the $\mathrm{PH}$ domain was observed to interact with anillin, a contractile ring protein that scaffolds actin and myosin and interacts with RhoA ${ }^{31}$. As one of at least 25 RhoGEFs that can activate the RhoA small GTPase, Ect2 was demonstrated in cell 

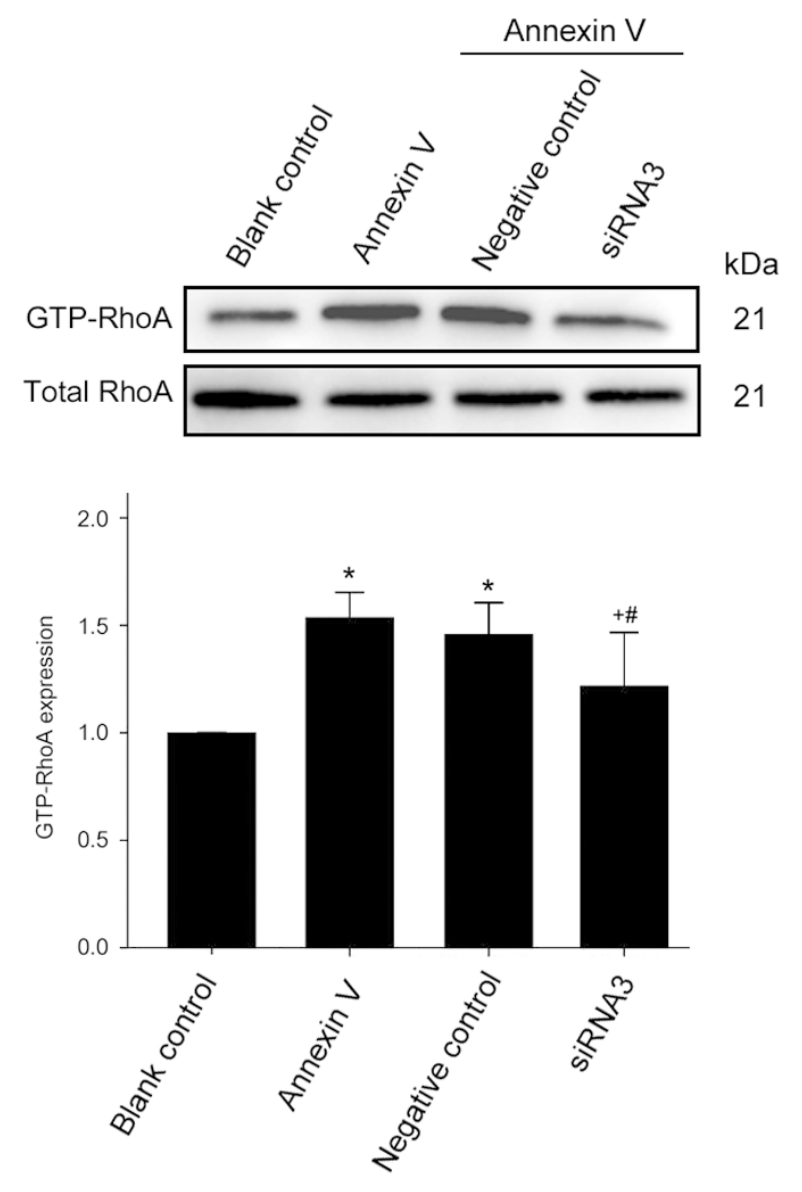

Annexin V

Figure $5 \mid$ Knockdown of Ect2 expression blocked annexin V-induced increase in RhoA activity. The cells were transfected without or with siRNA3 or scrambled siRNA (negative control), and the cells were then treated with blank control or annexin $\mathrm{V}$ for $48 \mathrm{~h}$. RhoA activity was measured using a pull-down assay as described in Methods $(n=3)$. ${ }^{*} P<0.01$ vs. Blank control; $+P<0.01$ vs. annexin $\mathrm{V}$; and $\# P<0.05$ vs. annexin $\mathrm{V}+$ Negative control.

culture studies with established cell lines as essential for mammalian cell cytokinesis and proliferation ${ }^{32}$. Using primary cells, a previous study showed that guanine exchange factors GEF-H1 and Ect2 must be downregulated for megakaryocyte polyploidization ${ }^{33}$. The Rho GTPase-activating protein (GAP) domain of CYK-4 was shown to promote the activation of RhoA during cytokinesis ${ }^{34}$. Both the guanine nucleotide exchange function and the membrane targeting of Ect 2 are essential for RhoA activation and cleavage furrow formation in human cells ${ }^{35}$. Ect2 has been demonstrated to subject to phosphorylation/dephosphorylation throughout the meiosis of oocytes, and PBI emission is temporally associated with Ect2 dephosphorylation too $^{36}$. These effects were associated with the inhibition of mitogeninduced activation of the MAPK pathway and the suppression of anillin, Ect2, and cyclin B1 among other proteins involved in mitosis, which would be expected to reduce the activation of endogenous RhoA at the cell equator ${ }^{37}$.

Consistent with these results, we reported that annexin $\mathrm{V}$ treatment also evoked a marked activation of RhoA, which was abolished by the knockdown of Ect 2 using siRNA, suggesting that RhoA is a downstream effector of Ect 2 activation. However, the activation mechanism of RhoA signaling has not yet been elucidated. Our results indicated that annexin $\mathrm{V}$-induced RhoA activation may account for Ect2-dependent increase of G2/M cell population. It is important to note that our data do not exclude the possibility that the effect of Ect 2 on annexin $\mathrm{V}$-induced Leydig cell proliferation may be mediated, at least in part, by RhoA/ROCK-independent pathways. For example, Ect2 had an intrinsically distinct GTPase specificity profile in the nucleus versus the cytoplasm, while nuclear Ect2 bound preferentially to Rac1, cytoplasmic Ect2 bound to RhoA ${ }^{38}$.

\section{Methods}

Reagents. Recombinant rat annexin V was synthesized in our laboratory ${ }^{39}$. The fulllength encoding sequence of rat annexin $\mathrm{V}$ was chemically synthesized and inserted into the HIS fusion expression vector pET28a. The expression of the fusion protein HIS-annexin V $(36 \mathrm{kDa})$ was induced by isopropyl-beta-D-thiogalactoside (IPTG) under the control of the T7 promoter, and the products were purified by affinity chromatography. The protein annexin $\mathrm{V}$ can be efficiently expressed in E. coli. The biological anticoagulation activity of annexin $\mathrm{V}$ was determined by the modified activated partial thromboplastin time (APTT) test, which confirmed that the synthesized annexin V has strong anticoagulant activity. Dulbecco's modified Eagle's medium (DMEM)/Ham's nutrient mixture F12 (DMEM/F12) was purchased from Invitrogen (Grand Island, NY, USA). Percoll, HEPES, collagenase type I were from Sigma-Aldrich Corporation (St Louis, MO, USA). The 3-(4, 5-dimethylthiazol-2yl) 2,5-diphenyl tetrazolium bromide (MTT) was obtained from Amresco Inc. (Solon, OH, USA). The Cell Cycle Detection Kit was obtained from Biovision (USA). Y27632 was purchased from Tocris (Bristol, UK). Rabbit anti-Ect2 polyclonal antibody and rabbit anti-annexin V polyclonal antibody was from Santa Cruz (CA, USA). Rabbit anti-RhoA polyclonal antibody, rabbit anti- $\beta$-actin antibody, and goat anti-rabbit secondary antibodies were purchased from Cell Signaling (USA).

Leydig cell isolation and culture. Male Sprague-Dawley rats (9-10 weeks old) were bred in our laboratory. The animal room was maintained at $22-24^{\circ} \mathrm{C}$ under a constant $12 \mathrm{~h}$ light:12 h darkness cycle. Animals were fed with standard pellet diet and water ad libitum. The procedure of animal experiments was performed following the guidelines for animal treatment of Nanjing Jinling Hospital and approved by the local ethics committee, which is in accordance with the principles and procedure of the NIH guide for the care and use of laboratory animals.

Leydig cells were prepared from the immature rat testes by collagenase treatment as described previously ${ }^{40}$. Briefly, decapsulated testes were incubated with collagenase $(0.25 \mathrm{mg} / \mathrm{mL})$ for $20 \mathrm{~min}$ at $37^{\circ} \mathrm{C}$. The crude interstitial cells were collected by centrifugation at $1,000 \times \mathrm{g}$ for $10 \mathrm{~min}$, and then washed twice with HBSS containing $0.1 \%(\mathrm{w} / \mathrm{v})$ BSA. To obtain pure Leydig cells, the crude cell suspension was loaded on top of a discontinuous Percoll gradient (20, 40, 60, and 90\% Percoll in HBSS) and subsequently centrifuged at $800 \times \mathrm{g}$ for $20 \mathrm{~min}$. The fractions enriched in Leydig cells were obtained and centrifuged in a continuous, self-generating density gradient starting with $60 \%$ Percoll at $20,000 \times \mathrm{g}$ for $30 \mathrm{~min}$ at $4{ }^{\circ} \mathrm{C}$.

The total number of cells and the percentage of $3-\beta$-HSD-positive cells were determined with this Leydig cell preparation ${ }^{41}$. The purity of the Leydig cells was $85-$ $90 \%$. The cell viability, as assessed by Trypan blue exclusion, was greater than $90 \%$. The purified Leydig cells were washed twice with DMEM-F/12 and resuspended in DMEM-F/12 supplemented with $15 \mathrm{mmol} / \mathrm{L}$ HEPES ( $\mathrm{pH} 7.4$ ), $1 \mathrm{mg} / \mathrm{mL}$ BSA, $365 \mathrm{mg} / \mathrm{L}$ glutamine, $100 \mathrm{IU} / \mathrm{mL}$ penicillin, and $100 \mu \mathrm{g} / \mathrm{mL}$ streptomycin.

For culturing, $2 \mathrm{~mL}$ cell suspension containing $10^{6}$ cells $/ \mathrm{mL}$ were placed into each well of 6-well plate (Costar, NY, USA) and incubated at $34^{\circ} \mathrm{C}$ in a humidified atmosphere of $5 \% \mathrm{CO}_{2}-95 \%$ air. Annexin V $(1 \mathrm{nmol} / \mathrm{L})$ was preincubated with sufficient $(10 \mathrm{nmol} / \mathrm{L})$ annexin $\mathrm{V}$ specific antibody for $1 \mathrm{~h}$ at $37^{\circ} \mathrm{C}$, which would inactivated annexin V function and served as negative control. The cells were incubated with fresh medium containing increasing concentrations of annexin $\mathrm{V}(0.1,1$, and $10 \mathrm{nmol} / \mathrm{L}$, respectively) or with blank control or negative control for different time $(0,12,24$, and $48 \mathrm{~h}$, respectively).

Transfection of siRNAs in Leydig cells. Three siRNA duplexes were synthesized commercially by Invitrogen with the help of tools available online

(cnservice.invitrogen.com). The sequences were as follows: siRNA1, 5'-GGU GUC UAC UUC AAA UGU U(dTdT)-3'; siRNA2, 5' -GCA AGG AGG UAC CUA UUU A(dTdT)-3'; and siRNA3, 5' -GCA GAU GCU GAG AAU CUU A(dTdT)-3'. They were designed to target different coding regions of the rat Ect 2 mRNA sequence (Gene Bank Accession NO. NM_001108547.2).

The day before transfection, $2 \times 10^{6}$ cells in $2 \mathrm{~mL}$ of DMEM without antibiotics were plated so that cells will be $70-90 \%$ confluent at the time of transfection. In the following day, the cells were transfected with siRNA in $50 \mu \mathrm{L}$ PBS at a final concentration of $100 \mathrm{nmol} / \mathrm{L}$. After mixing gently and incubating for $1 \mathrm{~min}$, the diluted GenEscortTM II at a final ratio of GenEscortTM II ( $\mu \mathrm{L})$ to siRNA $(\mu \mathrm{g})$ of $2: 1$ was added, mixed gently, and then incubated for 10-15 $\mathrm{min}$ at room temperature to allow transfection complex formation. After $48 \mathrm{~h}$ at $34^{\circ} \mathrm{C}$ with $5 \% \mathrm{CO}_{2}$, the transgene expression was tested. A control and a negative control were also contained in the 6well plates.

Cell viability detection by MTT assay. The MTT [3-(4,5-dimethyl-2-thiazolyl)-2,5diphenyl-2-H-tetrazolium bromide] assay is a colorimetric assay for assessing cell proliferation. Briefly, cells were plated onto a 96-well culture plate at $10^{4}$ cells/well in $100 \mu \mathrm{L}$ of culture medium. After the incubation, $20 \mu \mathrm{L}$ of MTT solution $(5 \mathrm{mg} / \mathrm{mL})$ were added into each well followed by further incubation for $4 \mathrm{~h}$. The supernatants 

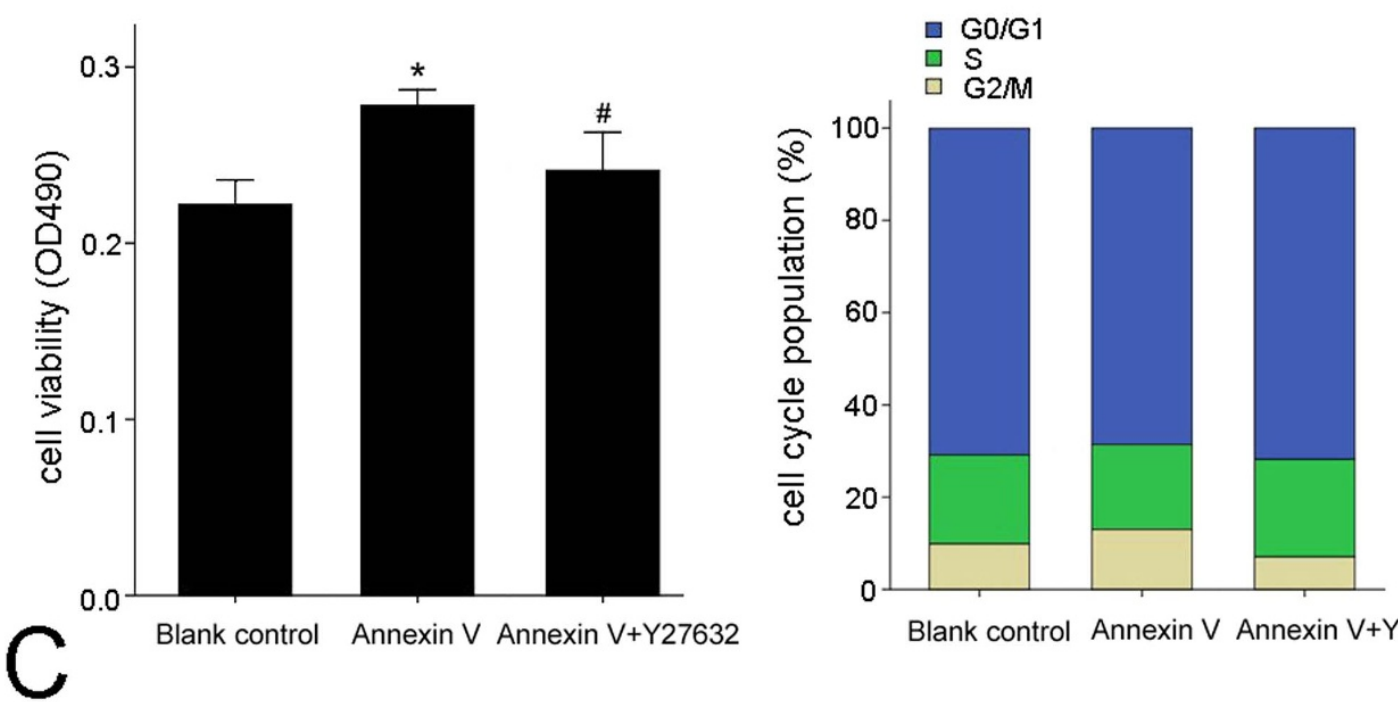

Blank control Annexin V Annexin V+Y27632
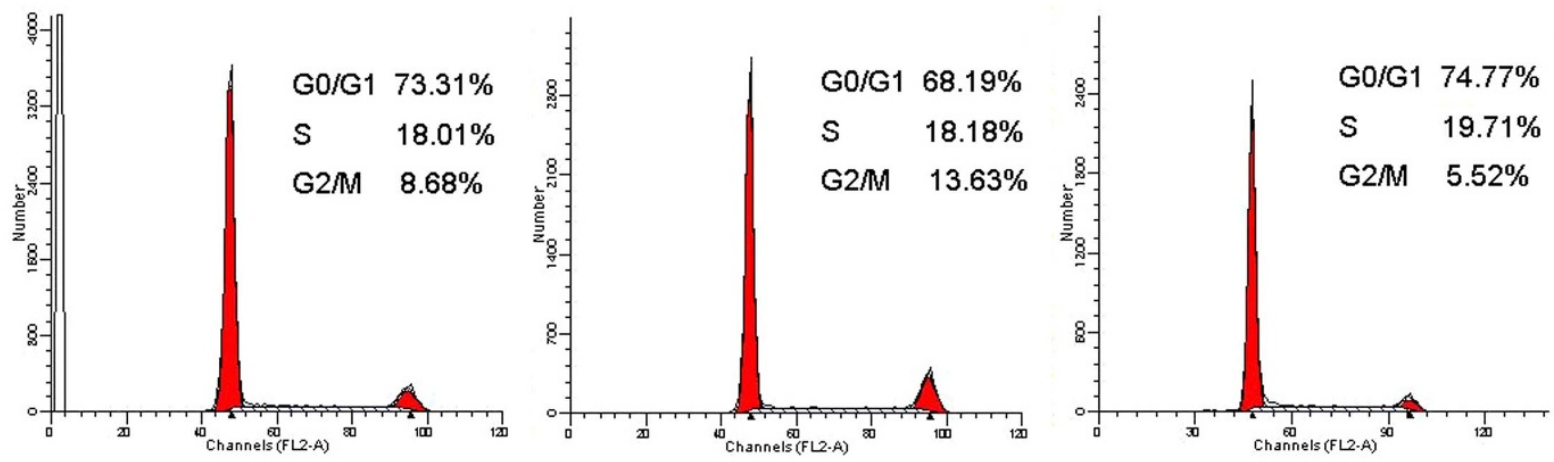

Figure 6 | Inhibition of ROCK attenuated annexin V-induced Leydig cell proliferation. Following pretreatment of cells with $10 \mu \mathrm{mol} / \mathrm{L}$ Y27632 (a selective inhibitor of ROCK) for $30 \mathrm{~min}$, then treated with blank control or annexin V for $48 \mathrm{~h}$. The MTT assay (A) and flow cytometry (B and C) were used to identify proliferation cells $(n=3)$. ${ }^{*} P<0.01$ vs. Blank control; $\# P<0.05$ vs. annexin $\mathrm{V}$.

were removed, and $150 \mu \mathrm{L}$ of DMSO were added into the wells to dissolve the formazan crystal. After 10 min of incubation at room temperature, the absorbance was measured on an automated microplate reader (Bio-Rad, Japan) at $490 \mathrm{~nm}$.

Cell cycle assay by flow cytometry. Cells were harvested in cold PBS, fixed in $70 \%$ alcohol, and stored at $4{ }^{\circ} \mathrm{C}$. The fixed cells were washed with PBS once and suspended in $500 \mu \mathrm{L}$ of PI staining solution containing $100 \mu \mathrm{g} / \mathrm{mL}$ RNAse A, and were then incubated in the dark for $30 \mathrm{~min}$. The cell cycle was measured by a Becton Dickinson FACS analysis system, and the quantitation of cell cycle distribution was carried out using Multicycle Software.

SDS-PAGE and Western blot analysis. Cells were washed twice with ice-cold PBS and lysed in $200 \mu \mathrm{L}$ of ice-cold RIPA buffer containing $150 \mathrm{mmol} / \mathrm{L} \mathrm{NaCl}, 1 \%$ Nonidet P-40, $0.25 \%$ deoxycholate, $0.1 \%$ sodium dodecyl sulfate (SDS), $50 \mathrm{mmol} / \mathrm{L}$ Tris (pH 7.4), $1 \mathrm{mmol} / \mathrm{L}$ phenylmethylsulfonyl fluoride (PMSF), $1 \mathrm{mmol} / \mathrm{L} \mathrm{Na}_{3} \mathrm{VO}_{4}$, and $1 \mathrm{mmol} / \mathrm{L} \mathrm{NaF}$. The cell lysate was harvested and centrifuged at $10,000 \times \mathrm{g}$ and $4{ }^{\circ} \mathrm{C}$ for $20 \mathrm{~min}$. The supernatants were collected to new tubes, and the protein concentration of supernatants was determined using Bradford method. The total protein $(30 \mu \mathrm{g})$ was then mixed with $6 \times$ loading buffer and boiled for $5 \mathrm{~min}$. The sample mixture was run on $15 \%$ SDS-PAGE gels in $1 \times$ running buffer at $25 \mathrm{~mA}$ for $2 \mathrm{~h}$. The protein was transferred to polyvinylidene difluoride membranes (PVDF; Millipore Corporation) at $70 \mathrm{~V}$ for $3.5 \mathrm{~h}$ in transfer buffer. Then, the membrane was blocked in TBST ( $0.5 \%$ Tween 20 in Tris-buffered saline) containing $5 \%(\mathrm{w} / \mathrm{v})$ non-fat dry milk at $37^{\circ} \mathrm{C}$ for $1.5 \mathrm{~h}$, and washed 3 times with TBST for $30 \mathrm{~min}$. The membranes were incubated with respective primary antibodies for $16-18 \mathrm{~h}$ at $4^{\circ} \mathrm{C}$. After washing, the membrane was incubated with horseradish peroxidase-conjugated secondary antibody, and the bands were visualized with ECL (Promega) as described by the manufacturer. The intensity of bands was quantitated by Quantity-One software.

RhoA activation assay. RhoA activity was measured using a Rho activation assay kit (Cytoskeleton) according to manufacturer's instructions. The cells were lysed in cell lysis buffer and cleared by centrifugation. The supernatants were incubated with Rhotekin-Rho binding domain (RBD) glutathione affinity beads, which specifically bind to GTP-bound RhoA. The beads were washed, and the immunoprecipitated complex was resuspended in $2 \times$ Laemmli sample buffer and subjected to $15 \%$ SDS-PAGE, followed by Western blot analysis. Total RhoA protein was determined in separate Western blots and used to normalize GTP-bound RhoA densitometricunits.

Statistical analysis. All data are expressed as mean \pm standard deviation. Standard deviation was illustrated by bars in Figures. The differences between the means were analyzed by one-way analysis of variance (ANOVA) and the least significance difference (LSD) method. $P$ values less than 0.05 were considered to be statistical significance.

1. Crompton, M. R., Moss, S. E. \& Crumpton, M. J. Diversity in the lipocortin/ calpactin family. Cell 55, 1-3 (1988).

2. Wallner, B. P. et al. Cloning and expression of human lipocortin, a phospholipase A2 inhibitor with potential anti-inflammatory activity. Nature 320, 77-81 (1986).

3. Pepinsky, R. B. et al. Five distinct calcium and phospholipid binding proteins share homology with lipocortin I. J Biol Chem 263, 10799-10811 (1988).

4. Iwasaki, A. et al. Structure and expression of cDNA for an inhibitor of blood coagulation isolated from human placenta: a new lipocortin-like protein. J Biochem 102, 1261-1273 (1987).

5. Shibata, S., Sato, H. \& Maki, M. Calphobindins (Placental Annexins) inhibit protein kinase C. J Biochem 112, 552-556 (1992).

6. Huber, R. et al. The calcium binding sites in human annexin $\mathrm{V}$ by crystal structure analysis at 2.0 A resolution. FEBS Lett 275, 15-21 (1990).

7. Gerke, V. \& Moss, S. E. Annexins: from structure to function. Physiol Rev $\mathbf{8 2}$, 331-371 (2002)

8. Kawaminami, M. et al. Association of annexin V with prolactin in the rat anterior pituitary gland. Biochem Biophys Res Commun 186, 894-898 (1992). 
9. Kawaminami, M. et al. Prolactin inhibits annexin 5 expression and apoptosis in the corpus luteum of pseudopregnant rats: involvement of local gonadotropinreleasing hormone. Endocrinology 144, 3625-3631 (2003).

10. Kawaminami, M. et al. Ovariectomy enhances the expression and nuclear translocation of annexin 5 in rat anterior pituitary gonadotrophs. Mol Cell Endocrinol 141, 73-78 (1998).

11. Kawaminami, M. et al. Immunocytochemical localization of annexin 5 , a calciumdependent phospholipid-binding protein, in rat endocrine organs. Cell Tissue Res 292, 85-89 (1998).

12. Kawaminami, M. et al. Gonadotropin-releasing hormone stimulates annexin 5 messenger ribonucleic acid expression in the anterior pituitary cells. Biochem Biophys Res Commun 291, 915-920 (2002).

13. Kawaminami, M. et al. Annexin 5 messenger ribonucleic acid expression in pituitary gonadotropes is induced by gonadotropin-releasing hormone $(\mathrm{GnRH})$ and modulates $\mathrm{GnRH}$ stimulation of gonadotropin release. Neuroendocrinology 75, 2-11 (2002).

14. Spreca, A. et al. Immunocytochemical localization of annexin V (CaBP33), a $\mathrm{Ca}(2+)$-dependent phospholipid- and membrane-binding protein, in the rat nervous system and skeletal muscles and in the porcine heart. J Cell Physiol 152, 587-598 (1992).

15. Giambanco, I. et al. Immunohistochemical localization of annexin V (CaBP33) in rat organs. J Histochem Cytochem 39, 1189-1198 (1991).

16. Yao, B. \& Kawaminami, M. Stimulation of annexin A5 expression by gonadotropin releasing hormone $(\mathrm{GnRH})$ in the Leydig cells of rats. J Reprod Dev 54, 259-264 (2008).

17. Ge, R. S. et al. Gene expression in rat Leydig cells during development from the progenitor to adult stage: a cluster analysis. Biol Reprod 72, 1405-15 (2005).

18. Yao, B. et al. Gonadotropin-releasing hormone positively regulates steroidogenesis via extracellular signal-regulated kinase in rat Leydig cells. Asia Journal of Andrology 13, 438-445 (2011).

19. Jing, J. et al. Differentially expressed proteins in the process of annexin 5 stimulating testosterone secretion from rat Leydig cells. Zhonghua Nan Ke Xue 18, 29-34 (2012).

20. Miki, T. et al. Oncogene ect2 is related to regulators of small GTP-binding proteins. Nature 362, 462-465 (1993).

21. Saito, S. et al. Rho exchange factor ECT2 is induced by growth factors and regulates cytokinesis through the $\mathrm{N}$-terminal cell cycle regulator-related domains. J Cell Biochem 90, 819-836 (2003).

22. Deguchi, M. et al. Expression of survivin during liver regeneration. Biochem Biophys Res Commun 297, 59-64 (2002).

23. Sakata, H. et al. A Rho-specific exchange factor Ect2 is induced from $\mathrm{S}$ to $\mathrm{M}$ phases in regenerating mouse liver. Hepatology 32, 193-9 (2000).

24. Tatsumoto, T. et al. Human ECT2 is an exchange factor for Rho GTPases, phosphorylated in G2/M phases, and involved in cytokinesis. J Cell Biol 147, 921-928 (1999).

25. Salhia, B. et al. The guanine nucleotide exchange factors trio, Ect2, and Vav3 mediate the invasive behavior of glioblastoma. Am J Pathol 173, 1828-38 (2008).

26. Petronczki, M. et al. Polo-like kinase 1 triggers the initiation of cytokinesis in human cells by promoting recruitment of the RhoGEF Ect2 to the central spindle. Dev Cell 12, 713-725 (2007)

27. Kimura, K. et al. Accumulation of GTP-bound RhoA during cytokinesis and a critical role of ECT2 in this accumulation. J Biol Chem 275, 17233-17236 (2000).

28. Kim, J. E. et al. The tandem BRCT domains of Ect2 are required for both negative and positive regulation of Ect2 in cytokinesis. J Biol Chem 280, 5733-5739 (2005).

29. Priya, R., Yap, A. S. \& Gomez, G. A. E-cadherin supports steady-state Rho signaling at the epithelial zonula adherens. Differentiation 86, 133-40 (2013).

30. Matthews, H. K. et al. Changes in Ect2 localization couple actomyosin-dependent cell shape changes to mitotic progression. Dev Cell 23, 371-83 (2012).

31. Frenette, P. et al. An anillin-Ect2 complex stabilizes central spindle microtubules at the cortex during cytokinesis. PLoS One 7, e34888 (2012).
32. Cook, D. R. et al. The ect2 rho Guanine nucleotide exchange factor is essential for early mouse development and normal cell cytokinesis and migration. Genes Cancer 2, 932-42 (2011).

33. Gao, Y. et al. Role of RhoA-specific guanine exchange factors in regulation of endomitosis in megakaryocytes. Dev Cell 22, 573-84 (2012).

34. Loria, A., Longhini, K. M. \& Glotzer, M. The RhoGAP domain of CYK-4 has an essential role in RhoA activation. Curr Biol 22, 213-9 (2012).

35. Su, K. C., Takaki, T. \& Petronczki, M. Targeting of the RhoGEF Ect2 to the equatorial membrane controls cleavage furrow formation during cytokinesis. Dev Cell 21, 1104-15 (2011)

36. Elbaz, J. et al. Epithelial cell transforming protein 2 (ECT2) depletion blocks polar body extrusion and generates mouse oocytes containing two metaphase II spindles. Endocrinology 151, 755-65 (2010).

37. Morin, P., Flors, C. \& Olson, M. F. Constitutively active RhoA inhibits proliferation by retarding $\mathrm{G}(1)$ to $S$ phase cell cycle progression and impairing cytokinesis. Eur J Cell Biol 88, 495-507 (2009).

38. Huff, L. P. et al. The role of Ect2 nuclear RhoGEF sctivity in ovarian cancer cell transformation. Genes Cancer 4, 460-75 (2013).

39. Tao, X. Q. et al. Expression of rat annexin 5 and its effect on human sperm motility in vitro. Zhonghua Nan Ke Xue 16, 400-4 (2010).

40. Svechnikov, K., Sultana, T. \& Soder, O. Age-dependent stimulation of Leydig cell steroidogenesis by interleukin-1 isoforms. Mol Cell Endocrinol 182, 193-201 (2001).

41. Payne, A. H., Downing, J. R. \& Wong, K. L. Luteinizing hormone receptors and testosterone synthesis in two distinct populations of Leydig cells. Endocrinology 106, 1424-1429 (1980).

\section{Acknowledgments}

This work was supported by the State Key Development Program for Basic Research of China (grant number 2013CB945200), the National Natural Science Foundation of China (grant number 31371520), the Natural Science Foundation of Jiangsu Province (grant number BK2010462) to B. Yao, and the Research Funds for Nanjing Jinling Hospital (grant number 2013043) to J. Jing.

\section{Author contributions}

B.Y., J.C.L. and Y.F.G. designed all the experiments; J.J., L.C., H.Y.F., K.F., Q.Y. and Y.F.G. performed the experiments. J.J. and L.C. wrote the manuscript while J.C.L. provided suggestions for revision. All authors reviewed the manuscript.

\section{Additional information}

Supplementary information accompanies this paper at http://www.nature.com/ scientificreports

Competing financial interests: The authors declare no competing financial interests.

How to cite this article: Jing, J. et al. Annexin V-induced rat Leydig cell proliferation involves Ect2 via RhoA/ROCK signaling pathway. Sci. Rep. 5, 9437; DOI:10.1038/srep09437 (2015)

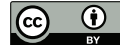

This work is licensed under a Creative Commons Attribution 4.0 International License. The images or other third party material in this article are included in the article's Creative Commons license, unless indicated otherwise in the credit line; if the material is not included under the Creative Commons license, users will need to obtain permission from the license holder in order to reproduce the material. To view a copy of this license, visit http://creativecommons.org/licenses/by/4.0/ 